\title{
PRÁVO NA OBHAJOBU V ŘÍZENÍ VEDENÉM ÚŘADEM EVROPSKÉHO VEŘEJNÉHO ŽALOBCE*
}

\author{
TOMÁŠ GŘIVNA
}

\begin{abstract}
The Rights of the Defence in Proceedings Conducted by the European Public Prosecutor's Office

The contribution reflects the EU Regulation 2017/1939 of 12th of October 2017, which executes the reinforced cooperation in order to establish the European Public Prosecutor's Office, with focus on the issue whether the establishment of the Office can have negative impact on the defence of the accused. Question arises, whether a certain disbalance may be created, with a specialized authoritative body of the Union to represent prosecution, and no body deemed to represent the accused is formed as a counterweight. In specific areas, some provisions of the regulation, that seem problematic from defence's viewpoint, are pointed out.
\end{abstract}

Keywords: The European Public Prosecutor's Office; right to criminal defence; European counsel

Klíčová slova: Úřad evropského veřejného žalobce; právo na obhajobu; evropský obhájce

DOI: $10.14712 / 23366478.2019 .39$

\section{1. ÚVOD}

Nařízením Rady (EU) 2017/1939 ze dne 12. října 2017, kterým se provádí posílená spolupráce za účelem zř́zení Ứradu evropského veřejného žalobce (dále jen „Nařízení“ a „Úřad“), došlo k naplnění článku 86 Smlouvy o fungování Evropské unie, byt' ,jen“ formou posílené spolupráce. Česká republika patří mezi státy, které vưli k posílené spolupráci projevily. ${ }^{1}$

Přijaté Nařízení je prŕmo aplikovatelným právním předpisem a vnitrostátní úprava je vůči němu subsidiární, jak se výslovně uvádí i v čl. 5 odst. 3 Nařízení (Vyšetřování a trestní stíhání vedená jménem Úřadu se řídí tímto nařízením. Vnitrostátní právo se použije v rozsahu, ve kterém není daná věc upravena tímto nařízením.). Subsidiárně se tedy bude aplikovat i trestní rád.

* Př́́spěvek je dedikován projektu PROGRES Q02 - Publicizace práva v evropském a mezinárodním srovnání.

1 Dalšími státy byly: Belgie, Bulharsko, Chorvatsko, Kypr, Finsko, Francie, Německo, Řecko, Litva, Lucembursko, Portugalsko, Rumunsko, Slovensko, Slovinsko a Španělsko. Později projevily přání účastnit se posílené spolupráce též Lotyšsko, Estonsko, Rakousko, Itálie. Po prrijetí nařízení se k posílené spolupráci prrihlásily též Nizozemí a Malta. 
Pokud jde o rozsah práv obviněných či podezřelých osob, nestanoví Nařízení v podstatě žádné odchylky od vnitrostátní úpravy. Stěžejní je v tomto směru čl. 41 (Rozsah práv podezřelých a obviněných osob) a korespondující recitál č. 83 až č. 85 . V čl. 41 se deklaruje, že činnosti Úřadu jsou prováděny při plném dodržování práv podezřelých a obviněných osob zakotvených v Listině, ${ }^{2}$ včetně práva na spravedlivý proces a práva na obhajobu. V odstavci druhém se připomíná, že podezřelá nebo obviněná osoba má $\mathrm{v}$ trestním ř́izení určitá minimální práva vyplývající $\mathrm{z}$ vyjmenovaných pěti směrnic ${ }^{3}$ se zdůrazněním národního aspektu (,jak byly provedeny ve vnitrostátním právu“). Jako jakési ujištění, že Nařízení nijak nesnižuje standard práv podezřelých či obviněných osob, působí poslední odstavec: Aniž jsou dotčena práva uvedená v této kapitole, mají podezřelé a obviněné osoby a ostatní osoby, kterých se řízení Úřadu týká, veškerá procesní práva, která jsou jim $\mathrm{k}$ dispozici podle př́slušného vnitrostátního práva, včetně možnosti provádět důkazy, vyžadovat jmenování znalců nebo posouzení znalcem a výslech svědkủ a požadovat, aby Úřad získal tato opatření v zájmu obhajoby.

V citovaných ustanoveních Nařízení sice právo na obhajobu deklaruje, nijak ho však neupravuje a jeho rozsah činí závislým na vnitrostátní právní úpravě. Obdobnou textaci, kdy je určité právo přiznáno, zároveň však vázáno na vnitrostátní úpravu, nalezneme i v dalších ustanoveních. Je tomu tak např. ve vztahu k nahlížení do spisu Úřadu, upravenému v čl. 45 odst. 2 (Spis bude spravovat evropský pověřený žalobce, který př́ípad projednává, v souladu s právními předpisy svého členského státu. [...] Evropský pověřený žalobce, který př́ípad projednává, umožní podezřelým a obviněným osobám i dalším osobám, kterých se řízení týká, př́istup ke spisu v souladu s vnitrostátním právem členského státu tohoto žalobce.)

\section{VYMEZENÍ PROBLÉMU}

Na první pohled by se zdálo, že přijetí a aplikace Nařízení nebude mít zásadní vliv na práva osoby, proti níž se řízení vede. Ostatně ani připravovaná novela trestního řádu (Sněmovní tisk č. 337, 8. volební období), kterou se má adaptovat stávající právní úprava, aby byla souladná a odpovídala Nařízení, nemění ustanovení trestního řádu týkající se obviněného a obhájce. Přesto lze vyslovit hypotézu, že přijaté Nařízení může mít podstatný vliv na obhajobu obviněného, podíváme-li se na Nařízení z praktického úhlu pohledu.

K podpoře této hypotézy lze zvolit několik modelových př́kladů:

2 V Listině základních práv Evropské unie jsou práva osob, proti nimž se vede trestní rízení, obsažena především v Hlavě VI. (Soudnictví), v čl. 47 (právo na účinnou právní ochranu a na spravedlivý proces), v čl. 48 (presumpce neviny a právo na obhajobu) a v čl. 50 (právo nebýt dvakrát trestně stíhán nebo trestán za stejný čin).

3 a) právo na tlumočení a překlad podle směrnice 2010/64/EU; b) právo na informace a př́stup k materiálům o př́ípadu podle směrnice 2012/13/EU; c) právo na přístup k obhájci a právo na komunikaci se třetími osobami a jejich informování v př́ípadě zatčení podle směrnice 2013/48/EU; d) právo nevypovídat a právo na presumpci neviny podle směrnice (EU) 2016/343; e) právo na právní pomoc podle směrnice (EU) 2016/1919. 


\subsection{VYŠETŘOVÁNÍ TZV. PŘESHRANIČNÍCH PŘÍPADU゚}

Úřad je v prvé řadě povolán vyšetř̌ovat trestné činy poškozující nebo ohrožující finanční zájmy Unie (viz čl. 22 odst. 1 Nařízení), které jsou stanoveny ve směrnici (EU) 2017/1371, jak byla provedena ve vnitrostátním právu, bez ohledu na to, zda by stejné trestné jednání mohlo být podle vnitrostátního práva kvalifikováno jako jiný druh trestného činu.

U některých z těchto činů (podle čl. 3 odst. 2 písm. d) směrnice) se pro založení př́slušnosti Úřadu mimo jiné vyžaduje, aby byly spojeny s územím nejméně dvou členských států.

Z hlediska místní př́islušnosti řízení zpravidla zahajuje a projednává evropský pověřený žalobce z členského státu, v němž se trestná činnost soustřed’uje, nebo - bylo-li spácháno několik souvisejících trestných činů spadajících do pravomoci Úřadu - z členského státu, v němž byla spáchána většina trestných činů (čl. 26 odst. 4 Nařízení; forum delicti comissi). Až do podání obžaloby zůstává stálé komoře oprávnění předat věc evropskému žalobci v jiném členském státě nebo rozhodnout o sloučení (nebo naopak rozdělení) věci a zároveň vybrat evropského veřejného žalobce, který prrípad projedná (čl. 26 odst. 5 Nařízení).

V uvedených případech může snadno dojít k tomu, že se řízení vede ve státě, ve kterém obviněný nemá bydliště, není jeho státním příslušníkem a nerozumí jazyku, ve kterém se řízení vede. Při změně evropského veřejného žalobce v důsledku sloučení nebo rozdělení věci se může změnit i dosavadní členský stát, ve kterém se řízení vedlo. Není to jen obtíž pro obviněného samotného, ale i pro jeho obhájce, který nejenže nemusí ovládat úřední jazyk jiného členského státu, ale ani znát cizozemskou právní úpravu. Tyto dva aspekty vyžadují určitou reakci. Zatímco Úřad s ohledem na jeho složení může relativně snadno oba problémy vnitřně vyřešit, obhajoba úřednickým aparátem nedisponuje. Naplno se zde projevuje nerovnost zbraní. Pouze ve velmi omezeném rozsahu může jazykovou bariéru odstranit tlumočník.

\subsection{NUTNOST ZNALOSTI CIZOZEMSKÉ PRÁVNÍ ÚPRAVY PRO POSOUZENÍ ZÁKONNOSTI ZÍSKANÉHO DŮKAZU}

Znalost cizozemské právní úpravy (a namnoze i cizozemské judikatury) bude potřebná i pro posouzení, zdali důkaz získaný v jednom členském státě je použitelný v řízení před soudem v jiném členském státě, jak umožňuje čl. 37 odst. 1 Nařízení:4 Důkazy, které žalobci Úřadu nebo žalovaný předloží soudu, nelze odmítnout pouze $\mathrm{z}$ důvodu, že byly shromážděny v jiném členském státě nebo v souladu s právem jiného členského státu.

Aniž by obhajoba měla reálnou možnost znát právní úpravu členského státu, ve kterém byl důkaz proveden, nemůže dost dobře namítat, že důkazy nebyly shromážděny v jiném členském státě v rozporu s jeho právní úpravou, resp. právní úpravou a jejím výkladem v soudní praxi daného členského státu.

4 Viz též recitál 80. 


\subsection{ROZDĚLENÍ PRAVOMOCÍ V RÁMCI ÚŘADU}

Úskalí přináší i samotné rozdělení pravomocí mezi pověřeného evropského Žalobce, tedy žalobce z př́slušného členského státu, a další orgány Úřadu (stálá komora, kolegium), nebot' tyto vystupují namísto vnitrostátního instančně nadřízeného státního zastupitelství, popř. i způsobem, kterým by nadřízené státní zastupitelství podle vnitrostátní právní úpravy postupovat nemohlo. Přritom postupují podle zásady nezávislosti a odpovědnosti (čl. 6), tedy jednají v zájmu Unie jako celku, nevyhledávají ani nepřijímají pokyny od žádné osoby mimo Úřad, od žádného členského státu Evropské unie ani od žádného orgánu, instituce nebo jiného subjektu Unie. Členské státy Evropské unie a orgány, instituce a jiné subjekty Unie respektují nezávislost Úřadu a nesnaží se jej ve výkonu jeho úkolů ovlivňovat.

Příkladem výkonu oprávnění odlišně od věcí, které nespadají do věcné příslušnosti Úřadu, patří např. o oprávnění stále komory (viz čl. 10) dát evropskému pověřenému Žalobci pokyn k zahájení vyšetřování (čl. 26 odst. 3); předat případ jinému evropskému pověřenému žalobci v tomtéž (čl. 28 odst. 3) nebo v jiném členském státě (čl. 26 odst. 5). Stálá komora též rozhoduje: o postoupení věci (čl. 34), o skončení vyšetřování (čl. 35), o podání opravného prostředku před vnitrostátním soudem (čl. 36 odst. 7), o odložení případu (čl. 39), o použití zvláštního způsobu řízení (čl. 40). Kolegium např. může vydat pokyn, umožňující evropským pověřeným žalobcům nezávisle a bez zbytečného odkladu rozhodnout, že daný případ prostřednictvím evokace nepřevezmou (čl. 27 odst. 8).

I to klade zvýšené nároky na obhajobu obviněného samotného a jeho obhájce, který tak bude muset znát nejen vnitrostátní právní úpravu a Nařízení, ale též např. jednací řád Úřadu, na který Nařizení odkazuje na několika místech jako na předpis řešící podrobnější otázky. Např. podle čl. 9 odst. 2 má stanovit podrobnosti týkající se způsobu, jakým kolegium vykonává obecné činnosti dohledu.

\section{K CHARAKTERU OMEZENÍ PRÁVA NA OBHAJOBU}

Uvedené př́klady podle mého názoru vedou ke dvěma závěrům. Za prvé, mám za to, že budou existovat dvě skupiny obviněných s rozdílným zacházením a postavením. Jedni, kteří budou stíháni Úřadem v režimu Nařízení a subsidiárně národního trestního řádu, a druzí, kteří budou stíháni orgány činnými v přípravném řízení pouze v režimu národního trestního řádu. Nakolik je taková nerovnost ústavně konformní, je otázkou, kterou se tento příspěvek nezabývá.

Za druhé, jsem přesvědčen, že osoby stíhané Úřadem mají de facto omezenou možnost plně uplatnit obhajobu, aniž by existovala odpovídající kompenzace. Faktická omezení mohou spočívat: a) v neznalosti jazyka, ve kterém se řízení vede, b) v neznalosti cizozemské právní úpravy členského státu, ve kterém se řízení vede, c) v neznalosti specifického řízení, které se vede z části podle Nařízení a jednacího řádu Úřadu. Dalo by se namítat, že i v době před zřízením Úřadu jsou vedena řízení s cizím státním příslušníkem, který nerozumí jazyku, ve kterém se řízení vede, podle pro něj neznámé práv- 
ní úpravy trestního řízení a může vždy využít právní pomoci advokátem z dotčeného členského státu. Na rozdíl od jiných prŕípadů, však v řízeních vystupuje Úřad, který je konstruován tak, že i v prrípadě změny evropského pověřeného žalobce, povede řízení osoba, která je znalá jazyka i práva členského státu, ve kterém se řízení vede, kontinuita je zajištěna i stálou komorou, která se v důsledku změny evropského pověřeného žalobce nemění.

\section{K MOŽNOSTEM, JAK FAKTICKÁ OMEZENÍ KOMPENZOVAT}

Považuji za vhodné, aby pro případ vedení trestního řízení, byla stanovena nutná obhajoba, nehledě na závažnost činu. I když bude zpravidla závažnost činu natolik vysoká, že připadá v úvahu nutná obhajoba právě z tohoto důvodu (v České republice podle $\S 36$ odst. 3 trestního řádu - řízení o trestném činu, na který zákon stanoví trest odnětí svobody, jehož horní hranice převyšuje pět let), v jiných členských státech tomu tak být nemusí. Navíc, jak plyne z čl. 22 Nařízení, Úřad bude (event. může být) př́islušný ve věci, kde je nižší i typová závažnost činu. De lege ferenda by měl být uvažován samostatný důvod nutné obhajoby.

Názory na nutnost otázku kompenzace nerovného postavení řešit, se objevují i v zahraničí, zejména v německy psané literatuře..$^{5}$ Jednotlivými autory jsou předkládány k úvaze možné návrhy řešení, od odvážného návrhu na zř́zení centralizovaného úřadu Evropské unie obdobného Evropskému veřejnému žalobci (tzv. úřad Eurodefensora) $\mathrm{s}$ decentralizovanými složkami, až k jednoduchým doporučením využívat stávajících možností právní úpravy jako je např. doporučení poskládat tým obhájců z různých členských zemí. Patrně nejucelenější přehled, a to i s odkazem na příspěvky jiných autorů, podává A. Jörg, ${ }^{6}$ který vypočítává tyto možnosti:

a) Zř́zení úřadu tzv. Eurodefensora. Úřad by byl ústřední institucí Evropské unie (na stejné úrovni jako je Úřad veřejného žalobce), přičemž ale nositeli jeho kompetencí by byli národní advokáti (nebo advokátní spolky). V jednotlivých členských státech by měl tento úřad zaměstnance a pobočky. Pravomocí úřadu by bylo jednak plnit úkoly pověřence pro ochranu práv osob, jednak by plnil úlohu servisní instituce, která by poskytovala informace o zahraniční právní úpravě, zprostředkovávala kontakty na zahraniční obhájce, event. by přikročila k finanční podpoře nemajetných obvině-

5 Srov. např. MAGNUS, D. Die endgültige EU-Verordnung zur Europäischen Staatsanwaltschaft - Der große Wurf? 2018 [online]. Dostupné z: https://www.hrr-strafrecht.de/hrr/archiv/18-04/index.php?sz=6\# ftn43. SCHÜNEMANN, B. -NESTLER, C. - SZWARC, A. J. - MITCHELL, J. In: SCHÜNEMANN, $\overline{\mathrm{B}}$. (Hrsg.). Ein Gesamtkonzept für die europäische Strafrechtspflege. Köln: Carl Heymann Verlag, 2006. Vogel ZStW 116 (2004), 400, 414. Viz také SAFFERLING, Ch. instruktiv zum Prinzip der Waffengleichheit im Europäischen Rechtsraum. NStZ 2004, 181, 182. SCHÜNEMANN, B. (Hrsg.). Alternativentwurf Europäische Strafverfolgung. Köln: Carl Heymann Verlag, 2004, (zu Art. 111-174 a). AGIS-Arbeitsgruppe in: SCHÜNEMANN, B. (Hrsg.). Ein Gesamtkonzept für die europäische Strafrechtspflege. PETERS, A. Die Europäische Staatsanwaltschaft - Eine Gefahr für den fair trial-Grundsatz? 2014 [online]. Dostupné z: https://verfassungsblog.de/europaeische-staatsanwaltschaft-gefahr-fuer-fair-trial-grundsatz/.

6 JÖRG, A. Vorschläge zur Verbesserung des Schutzes des Strafverteidigers: Auf dem Weg zu einem ,,europäischen“ Strafverteidiger? 2008 [online]. Dostupné z: https://www.hrr-strafrecht.de/hrr/archiv/08-01 /index.php?sz=6\#_ftn38. 
ných, pakliže by podle vnitrostátní právní úpravy nebyly pro bezplatnou obhajobu splněny podmínky. Eurodefensor (analogicky k evropskému veřejnému žalobci) by měl oprávnění vstupovat na podporu obhajoby do trestních řízení o přeshraničních závažných trestných činech, zprostředkovával by kontakty na obhájce, koordinoval obhajobu v př́padě plurality obhájců činných ve více státech, zajištoval by výměnu informací, finančně by zajišt'oval náklady obhajoby.

b) Zřízení nebo rozšíření oprávnění Ombudsmana. Jeho úlohou by bylo v přeshraničních vyšetřováních vyjádřit se, předtím, než soudy rozhodnou, $\mathrm{k}$ výkonu donucovacích opatření, jimiž se zasahuje do základních práv a svobod, především k tomu, zda jsou v konkrétním prŕpadě pro takové opatření splněny podmínky, dále by se mohl v postavení obdobném obhájci účastnit výslechu obviněných a svědků.

c) Zř́zzení institutu tzv. Ombudsperson. Tento institut navrhuje mimo jiných též CCBE (The Council of Bars and Law Societies of Europe). Na rozdíl od ombudsmana (viz výše) by tato osoba nebyla činná z podnětu Eurodefensora, ale z podnětu konkrétních osob zúčastněných na trestním řízení. Měl by především koordinační a monitorovací funkce.

d) Zř́zení Evropské asociace trestní obhajoby (Europäischer Strafverteidigungsverbund). Tento návrh se opírá o naléhavou potřebu další harmonizace obhajovacích práv. Členové asociace by měli stejné postavení jako vnitrostátní obhájci.

e) Zř́zení Evropské sítě trestních obhájců (Europäisches Netzwerk von Strafverteidigern). Do sítě trestních obhájců by se mohli advokáti zapojit po získání akreditace, osvědčující jejich znalosti a zkušenosti v obhajobě s mezinárodním rozměrem. Systém by mohl být spravován CCBE. Vnitrostátní orgány i Úřad by měly informační povinnosti, tedy obviněné informovat o tom, že existuje tato sít' a o právu na právní pomoc. Záleželo by na obviněném, zdali se na akreditovaného obhájce obrátí, nebo nikoliv.

f) Doporučení skládat obhajovací týmy z obhájců různých státních př́slušností.

g) Doporučení využívat institutu Evropského advokáta (srov. § $35 \mathrm{f}$ až $35 \mathrm{n}$ zákona č. 85/1996 Sb., o advokacii).

Z uvedených možností se mi jako reálná jeví možnost zřízení Evropské sítě trestních obhájců, která by byla zároveň platformou pro výměnu informací o cizozemských právních úpravách a síti kontaktů obhájců, kteří chtějí vykonávat obhajobu ve věcech, které vede Úřad. Naopak, zřízení instituce Eurodefensora se mi nejeví jako reálné, už jen $\mathrm{z}$ toho hlediska, že by obhajobu měli primárně vykonávat obhájci smluvní, bez zásahu nadstátní instituce.

\section{ZÁVĚR}

Ukazuje se, že jakkoliv Nařízení de iure nijak nemění právo na obhajobu, de facto $\mathrm{v}$ ŕízeních, která povede Úřad, mohou nastat situace, kde právo na obhajobu je de facto omezeno (jazyková bariéra, neznalost cizozemských právních úprav, specifické rozdělení pravomocí $\mathrm{v}$ rámci Ưřadu, nutná znalost Nařízení a jednacího řádu Úřadu). Taková faktická omezení vyžadují určitou formu kompenzace. Mám za to, že 
by v každém př́ípadě mělo být vedení rízení Úřadem důvodem nutné obhajoby, nehledě na typovou závažnost činu. Stejně tak se domnívám, že je namístě zohlednit specifika řízení i zavedením určité protiváhy Evropského veřejného žalobce, minimálně formou Evropské sítě trestních obhájců. Zdá se mi, že některá další z prezentovaných řešení nejsou s to odstranit jazykový handicap a zprostředkovat znalost cizozemské úpravy dostatečně rychle a efektivně. Různorodost jednotlivých návrhů ukazuje absenci širší shody na jednom z nich. Na druhou stranu je důkazem, že situace řešení vyžaduje. Naléhavost řešení bude stoupat s prvními přeshraničními př́ípady, které bude Úřad řešit. Lze očekávat, že tyto otázky znovu zazní ke konci roku 2020, resp. v roce 2021, kdy se předpokládá, že Úřad začne plnit své úkoly. ${ }^{7}$

doc. JUDr. Tomáš Gřivna, Ph.D.

Právnická fakulta Univerzity Karlovy

grivna@prf.cuni.cz

7 Úřad začne plnit své úkoly v rámci vyšetřování a trestního stíhání, které mu toto nařízení ukládá, ode dne, který po zrrízení Úřadu určí Komise rozhodnutím na návrh evropského nejvyššího žalobce. Den určený Komisí nesmí nastat dříve než tři roky po dni vstupu tohoto Nařízení v platnost, tedy nejdříve 20. listopadu 2020 . 